Юрчик Г. М., к.е.н., доцент, Коваль А., студент (Національний університет водного господарства та природокористування, м. Рівне)

\title{
ТЕНДЕНЦІЇ РОЗВИТКУ ТА СОЦІАЛЬНО-ЕКОНОМІЧНА ЗНАЧИМІСТЬ МАЛОГО БІЗНЕСУ В УКРАЇНІ
}

Конкретизовано критерії ідентифікації малого бізнесу в Україні та іноземних державах. Проаналізовано основі тенденції розвитку малого бізнесу в національній економіці. Визначено значимість малого бізнесу в економічному та соціальному розвитку держави. 3апропоновано пріоритетні напрями стимулювання малого бізнесу в Україні.

Ключові слова: бізнес, малий бізнес, підприємництво.

Вступ. Розбудова соціально орієнтованої економіки в Україні потребує розширення підприємницьких ініціатив населення, всебічного сприяння розвитку малого бізнесу (МБ). Як свідчить досвід розвинених держав, МБ визначає темпи економічного зростання, сприяє зміцненню конкурентного середовища та вирішенню соціальних проблем. За темпами розвитку МБ Україна, на жаль, суттєво відстає від провідних країн світу, що стримує їі інноваційний розвиток, обмежує можливості держави для підвищення соціальних стандартів життя населення. У зв'язку з цим, актуалізуються необхідність наукового дослідження тенденцій розвитку та значимості МБ у забезпеченні соціально-економічного розвитку держави та їі регіонів.

Аналіз останніх досліджень. Серед вітчизняних вчених найбільш помітний внесок у досілдження різних аспектів розвиту МБ здійснили А.Б. Альохіна, А.І. Бутенко, З.С. Варналій, С.М. Злупко, А. І. Даниленко, Г. В.Карпінська, В.А. Онищенко, Л.М. Ніколаєва, М.В. Сизоненко, Д.М. Стеченко та ін. Віддаючи належне досягнутим результатам, все ж проблема розвитку МБ як стратегічного чинника соціально-економічних змін потребує постійного опрацювання.

Постановка завдання. Метою даної статті $є$ дослідження тенденцій та значимості МБ в контексті підвищення ефективності використання його потенціалу у забезпеченні соціального та економічного розвитку держави.

Наукові результати. Бізнес-діяльність здійснюється в різних масштабах. Світовий досвід господарювання свідчить, що загальноприйнятим $€$ поділ бізнесу на малий, середній та великий. В загальносвітовій практиці не розроблено єдиних підходів до ідентифікації 
суб'єктів МБ. Основними критеріями ідентифікації МБ в практиці іноземних держав та Україні $\epsilon$ чисельність працівників та обсяги обороту, але при необхідності можуть також враховуватися й інші показники (табл. 1).

Таблиця 1

Критерії визначення суб'єктів малого бізнесу у країнах світу

\begin{tabular}{|c|c|c|c|}
\hline Країна & Чисельність зайнятих, осіб & $\begin{array}{c}\text { Річний обсяг } \\
\text { реалізації }\end{array}$ & Статутний фонд \\
\hline $\begin{array}{c}\text { Європейський } \\
\text { союз }\end{array}$ & до 50 & $\begin{array}{c}\text { до 4,0 млн } \\
\text { євро } \\
\end{array}$ & до 2,0 млн євро \\
\hline США & $\begin{array}{c}\text { - обробна промисловість: } \\
\text { до 1000; } \\
\text { - інші сфери: до } 100 .\end{array}$ & - & - \\
\hline Росія & до 100; & 400 млн руб & - \\
\hline Японія & $\begin{array}{l}\text { - обробна промисловість, } \\
\text { транспорт: до } 300 ; \\
\text { - оптова торгівля: до } 100 ; \\
\text { - роздрібна торгівля та інші: } \\
\text { до } 50 .\end{array}$ & - & $\begin{array}{c}\text { - обробна промисловість, } \\
\text { транспорт: до } 100 \text { млн йен; } \\
\text { - оптова торгівля: до } 30 \text { млн йен; } \\
\text { - роздрібна торгівля та інші: } \\
\text { до } 10 \text { млн йен. } \\
\end{array}$ \\
\hline Україна & до 50 & до 10 млн євро & - \\
\hline
\end{tabular}

Крім того, в Україні поміж суб'єктів МБ прийнято виділяти суб'єктів мікропідприємництва, до яких відносяться фізичні та юридичні особи, у яких середня кількість працівників не перевищує 10 осіб, а річний дохід від діяльності не перевищує 2 млн євро.

Результати аналізу офіційних статистичних даних свідчать про те, що протягом 2010-2017 рр. в Україні спостерігається постійна зміна кількості суб'єктів МП (табл. 2). Зокрема, протягом 2010-2015 рр. загальна кількість суб'єктів МБ постійно зростала, водночас з 2016 р. спостерігається тенденція до ї̈ зменшення. Показово, що суб'єкти МБ складають близько 99\% загальної кількості суб'єктів підприємництва, в той час як частка суб'єктів середнього та великого бізнесу складає лише близько 1\%. Поміж суб'єктів МБ понад 80\% складають фізичні особи-підприємці. Їх кількість протягом останніх років дещо зменшилась та у 2017 р. склала 1,47 млн осіб або 345 осіб на 10 тис. осіб наявного населення. На відміну від кількості фізичних осібпідприємців, кількість малих підприємств протягом 2017 р. зросла 10,9\%, сягнувши 76 од. на 10 тис. осіб наявного населення.

Аналіз даних свідчить, що визначальна роль у розвитку МБ в Україні належить суб'єктам мікропідприємництва (їх частка в загальність кількості суб'єктів підприємництва перевищує 95\%). Тенденції зміни суб'єктів мікропідприємництва в Україні аналогічні закономірностям розвитку МБ в цілому. 
Показники розвитку малого бізнесу в Україні, 2010-2017рр. (побудовано за даними [3])

\begin{tabular}{|c|c|c|c|c|c|c|c|c|}
\hline & 2010 & 2011 & 2012 & 2013 & 2014 & 2015 & 2016 & 2017 \\
\hline $\begin{array}{c}\text { Суб'єкти малого підприємництва } \\
\text { (з урахуванням мікропідприємництва), одиниць }\end{array}$ & 2162004 & 1679902 & 1578879 & 1702201 & 1915046 & 1958385 & 1850034 & 1789406 \\
\hline \% до попереднього року & - & 77,7 & 94,0 & 107,8 & 112,5 & 102,3 & 94,5 & 96,7 \\
\hline \% до всіх суб'єктів підприємництва & 99 & 98,7 & 98,7 & 98,9 & 99,1 & 99,2 & 99,2 & 99,1 \\
\hline \multicolumn{9}{|l|}{ малі підприємства } \\
\hline усього, одиниць & 357241 & 354283 & 344048 & 373809 & 324598 & 327814 & 291154 & 322920 \\
\hline \% до попереднього року & - & 99,2 & 97,1 & 108,7 & 86,8 & 101,0 & 88,8 & 110,9 \\
\hline відсотків до загальної кількості суб'єктів & 16,4 & 20,8 & 21,5 & 21,7 & 16,8 & 16,6 & 15,6 & 17,9 \\
\hline на 10 тис. осіб наявного населення, одиниць & 78 & 77 & 76 & 82 & 76 & 77 & 68 & 76 \\
\hline \multicolumn{9}{|l|}{ фізичні особи-підприємці } \\
\hline усього, одиниць & 1804763 & 1325619 & 1234831 & 1328392 & 1590448 & 1630571 & 1558880 & 1466486 \\
\hline \% до попереднього року & & 73,5 & 93,2 & 107,6 & 119,7 & 102,5 & 95,6 & 94,1 \\
\hline відсотків до загальної кількості суб'єктів & 82,6 & 77,9 & 77,2 & 77,1 & 82,3 & 82,6 & 83,6 & 81,2 \\
\hline на 10 тис. осіб наявного населення, одиниць & 394 & 290 & 271 & 292 & 370 & 381 & 365 & 345 \\
\hline Суб'єкти мікропідприємництва, одиниць & 2093688 & 1608819 & 1510776 & 1637180 & 1859887 & 1910830 & 1800736 & 1737082 \\
\hline \% до попереднього року & - & 76,8 & 93,9 & 108,4 & 113,6 & 102,7 & 94,2 & 96,5 \\
\hline \% до всіх суб'єктів підприємництва & 95,9 & 94,5 & 94,4 & 95,1 & 96,3 & 96,8 & 96,5 & 96,2 \\
\hline \multicolumn{9}{|l|}{ мікропідприємства } \\
\hline усього, одиниць & 300445 & 295815 & 286461 & 318477 & 278922 & 284241 & 247695 & 278102 \\
\hline \% до попереднього року & - & 98,5 & 96,8 & 111,2 & 87,6 & 101,9 & 87,1 & 112,3 \\
\hline відсотків до загальної кількості суб'єктів & 13,8 & 17,4 & 17,9 & 18,5 & 14,4 & 14,4 & 13,3 & 15,4 \\
\hline на 10 тис. осіб наявного населення, одиниць & 66 & 65 & 63 & 70 & 65 & 66 & 58 & 65 \\
\hline \multicolumn{9}{|l|}{ фізичні особи-підприємці } \\
\hline усього, одиниць & 1793243 & 1313004 & 1224315 & 1318703 & 1580965 & 1626589 & 1553041 & 1458980 \\
\hline \% до попереднього року & & 73,2 & 93,2 & 107,7 & 119,9 & 102,9 & 95,5 & 93,9 \\
\hline відсотків до загальної кількості суб'єктів & 82,1 & 77,2 & 76,5 & 76,6 & 81,8 & 82,4 & 83,2 & 80,8 \\
\hline на 10 тис. осіб наявного населення, одиниць & 391 & 287 & 269 & 290 & 368 & 380 & 364 & 343 \\
\hline
\end{tabular}


Переважна більшість суб'єктів МБ в Україні зосереджена в сфері торгівлі (46\%). Також досить привабливими для МБ (хоча і в меншій мірі порівняно з торгівлею) $є$ такі види діяльності як інформація телекомунікації (7\%), транспорт та складське господарство (5\%), промисловість (7\%) та ін. (рис. 1).

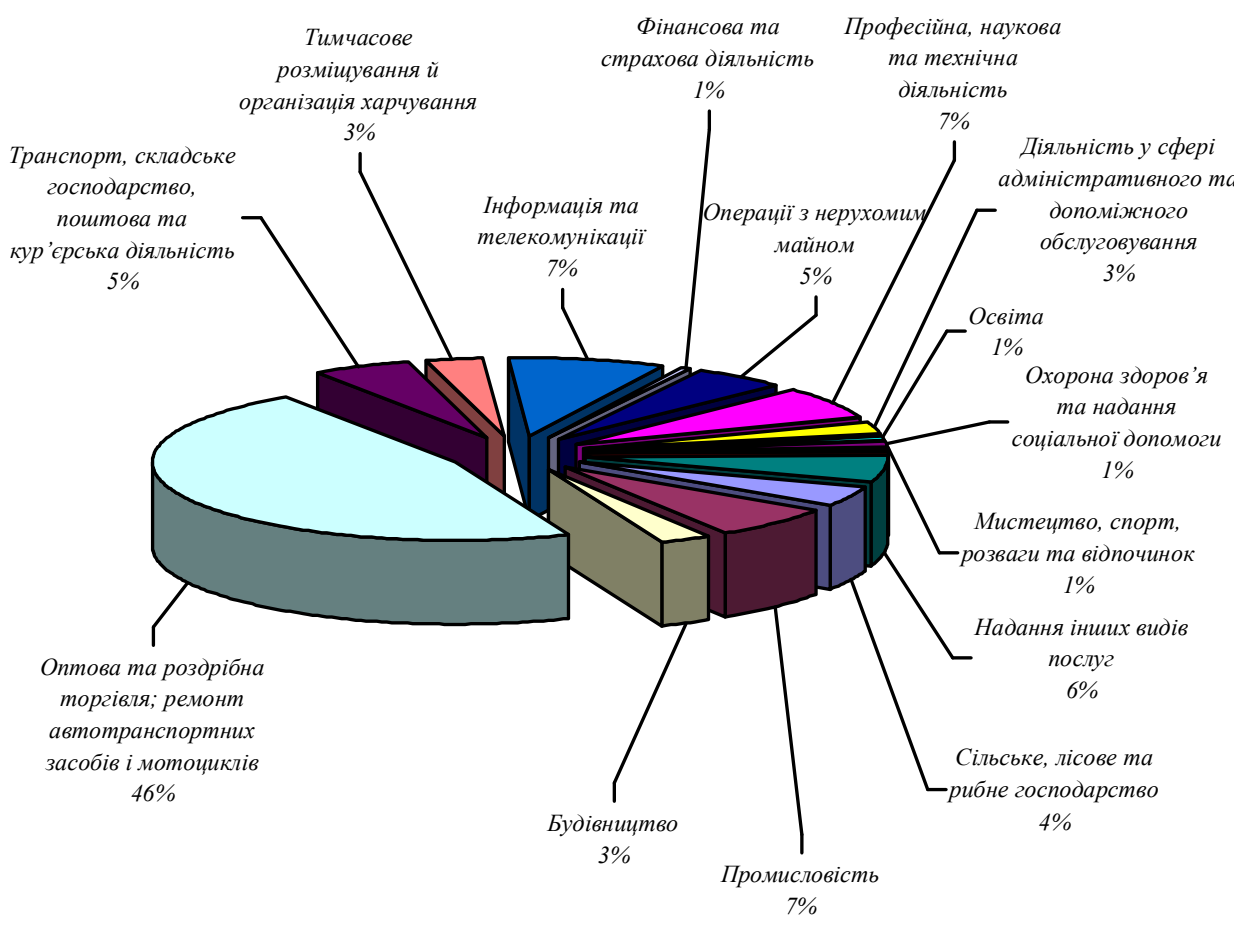

Рис. 1. Розподіл суб'єктів малого бізнесу за видами економічної діяльності в Україні (2017р.), \% [3]

МБ сприяє позитивним економічним та соціальним тенденціям в розвитку регіонів та країни в цілому. Слід відзначити, що МБ виконує низку специфічних соціально-економічних функцій (рис. 2).

Економічна функція МБ виражається в стимулюванні економічного розвитку держави та їі регіонів, раціональному використанню місцевих ресурсів, активізації конкурентного середовища, збільшенні бази оподаткування тощо.

Характеризуючи значення соціальної функції МБ, очевидно, що вона сприяє розвитку людського капіталу, зниженню рівня бідності та безробіття населення, зниженню рівня соціальної напруги, активізації підприємницьких ініціатив населення та зниженні утриманських настроїв. Соціальну функцію МБ інколи іменують «соціальним амортизатором». У соціальній сфері МБ виконує функцію «соціально- 
го амортизатора» через попередження та пом'якшення наслідків соціальних ризиків (безробіття, бідність, соціальна напруга, надмірна диференціація доходів, соціальна ізоляція).

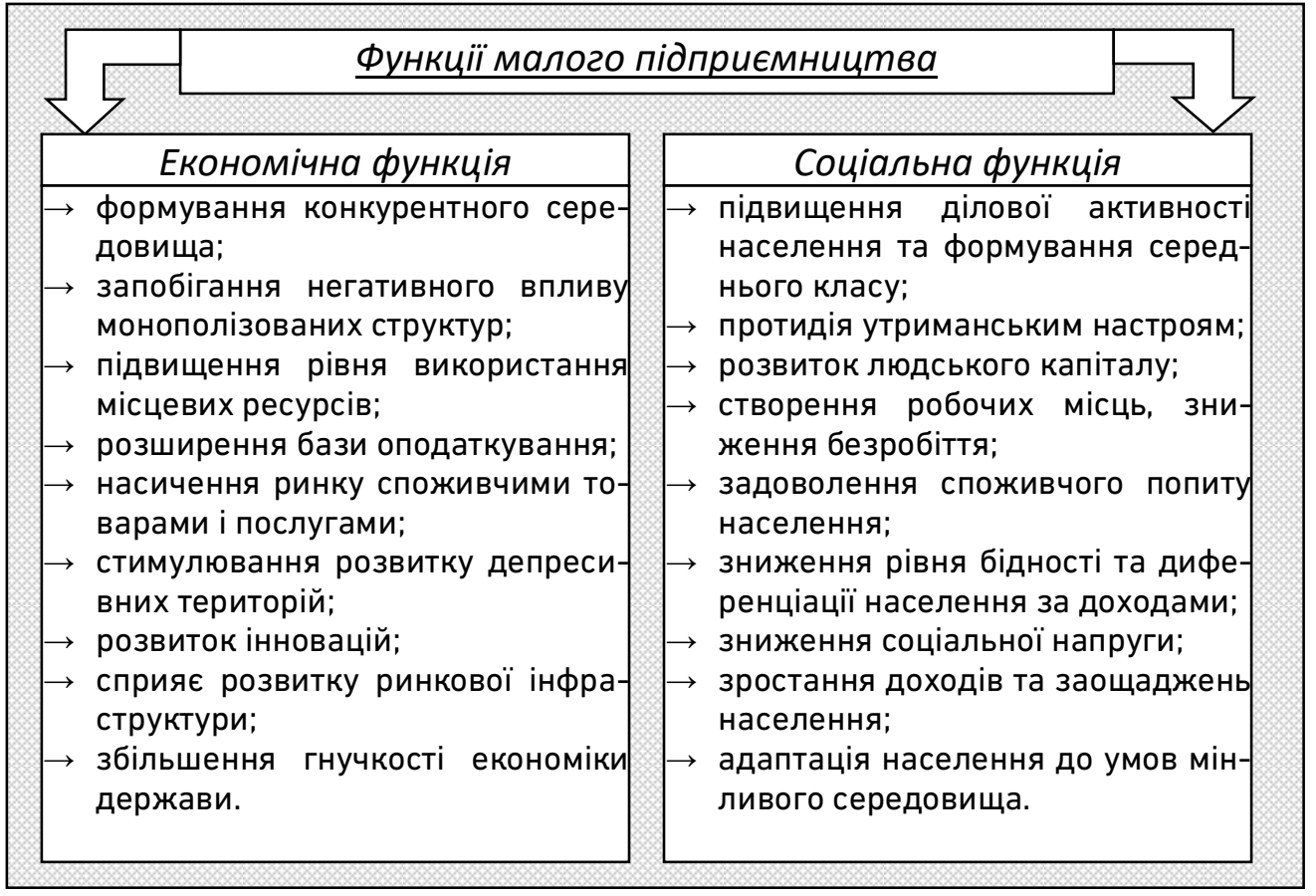

Рис. 2. Функції малого бізнесу (узагальнено авторами на основі [1; 2; 6; 7])

Дослідження економічної значимості МБ в Україні на основі ряду показників (табл. 3) свідчить, що відносні показники МБ у показниках макроекономічного розвитку держави є досить значними. Так, протягом 2013-2017 рр. МБ забезпечував створення від 19,8 до 24,7\% всього обсягу товарів, робіт, послуг в державі. Близькими до попереднього показника є частка доданої вартості МБ у загальній доданій вартості (19,3-24,0\%) та обсягу реалізованої продукції (товарів, послуг) у їх загальному обсязі (від 21,6-24,9\%).

Таким чином, значимість МБ у економічному розвитку держави та її регіонів є очевидною.

Окрім економічної, МБ має і соціальну значимість. Перш за все, МБ забезпечує створення робочих місць, а відтак сприяє зайнятості населення. Як свідчать дані (рис. 2), в МБ зайнято близько 43-47\% всього зайнятого населення та 34-36\% найманих працівників.

Крім того, МБ забезпечує формування трудових доходів населення у вигляді заробітної плати, що у 2017 р. в середньому на одного працівника складала 5344 грн./місяць, а також соціальне страхування працівників в системі загальнообов'язкового державного соціального страхування (табл. 4). 
Таблиця 3

Показники участі малого бізнесу в макроекономічному розвитку держави, 2013-2017 рр. [3]

\begin{tabular}{|c|c|c|c|}
\hline Роки & $\begin{array}{c}\text { Частка обсягу виробленої } \\
\text { продукції (товарів, послуг) } \\
\text { суб'єктів МБ у загальному } \\
\text { обсязі виробленої продукції } \\
\text { (товарів, послуг) суб'єктів го- } \\
\text { сподарювання, у\% }\end{array}$ & $\begin{array}{c}\text { Частка доданої вартості } \\
\text { за витратами виробницт- } \\
\text { ва суб'єктів МБ у загаль- } \\
\text { ній доданій вартості за } \\
\text { витратами виробництва } \\
\text { суб'єктів господарювання, } \\
\text { у \% }\end{array}$ & $\begin{array}{c}\text { Частка обсягу реалізова- } \\
\text { ної продукції (товарів, по- } \\
\text { слуг суб'єктів МБ у зага- } \\
\text { льному обсязі реалізова- } \\
\text { ної продукції (товарів, по- } \\
\text { слуг) суб'єктів господарю- } \\
\text { вання, у \% }\end{array}$ \\
\hline 2013 & 19,8 & 20,0 & 21,6 \\
\hline 2014 & 21,3 & 21,1 & 22 \\
\hline 2015 & 21,6 & 19,3 & 23,7 \\
\hline 2016 & 24,0 & 21,3 & 24,5 \\
\hline 2017 & 24,7 & 24,0 & 24,9 \\
\hline
\end{tabular}

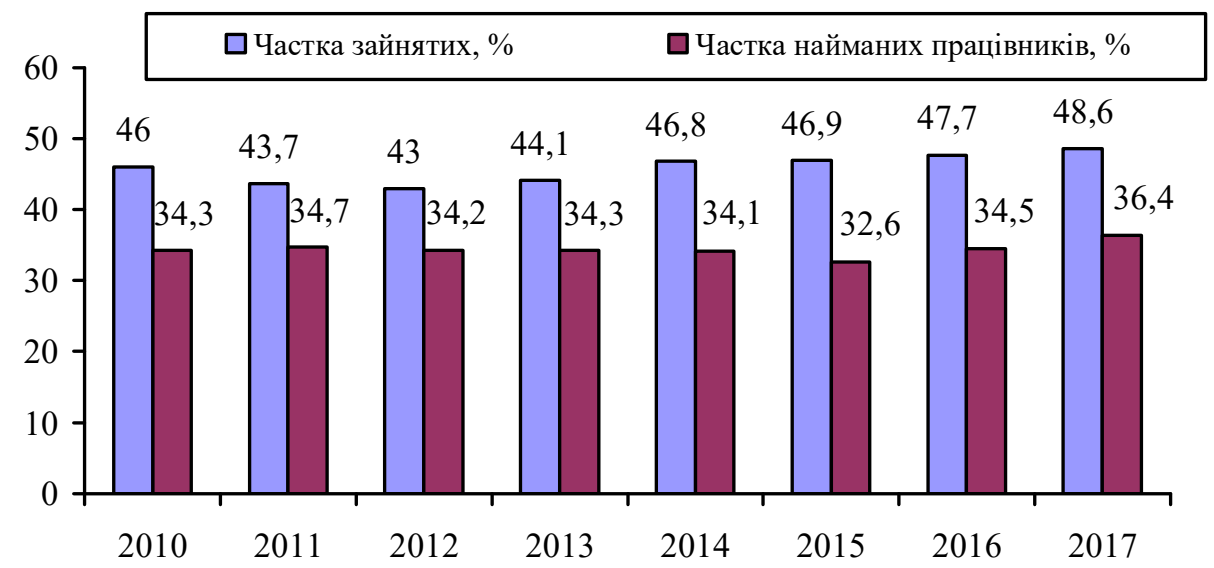

Рис. 2. Соціальна значимість малого бізнесу на ринку праці [3]

Таблиця 4

Витрати МБ на оплату праці та соціальне страхування працівників, 2013-2017 pp. [3]

\begin{tabular}{|c|c|c|c|c|}
\hline \multirow{2}{*}{ Роки } & \multicolumn{2}{|c|}{ Витрати МБ на оплату праці } & \multicolumn{2}{|c|}{$\begin{array}{r}\text { Відрахування на соціальні } \\
\text { заходи, млн грн. }\end{array}$} \\
\cline { 2 - 5 } & $\begin{array}{c}\text { загалом, } \\
\text { млн грн. }\end{array}$ & $\begin{array}{c}\text { в розрахунку на од- } \\
\text { ного працівника, } \\
\text { грн./місяць }\end{array}$ & $\begin{array}{c}\text { загалом, } \\
\text { млн грн. }\end{array}$ & $\begin{array}{c}\text { в розрахунку на } \\
\text { одого працівни- } \\
\text { ка, грн./місяць }\end{array}$ \\
\hline 2013 & 60117,4 & 2648,2 & 21458,7 & $9-45,3$ \\
\hline 2014 & 55475,3 & 2920,4 & 19939,7 & 1049,7 \\
\hline 2015 & 59652,8 & 3390,2 & 20932,9 & 1189,7 \\
\hline 2016 & 71906,7 & 3979,2 & 17970,5 & 994,4 \\
\hline 2017 & 100199,4 & 5344,3 & 24578,8 & 1311,0 \\
\hline
\end{tabular}


Статистична служба ЄC в цілях моніторингу розвитку бізнесу згруповує показники для малого і середнього бізнесу (МСБ). Відтак, в цілях коректності порівняння показників $Є С$ та України на рис. 3 наведено показники соціально-економічної значимості МСБ. Аналіз свідчить, що показники соціально-економічної значимості МСБ в Україні $€$ навіть дещо вищими порівняно з ЄС, зокрема, вищою $є$ частка зайнятих.

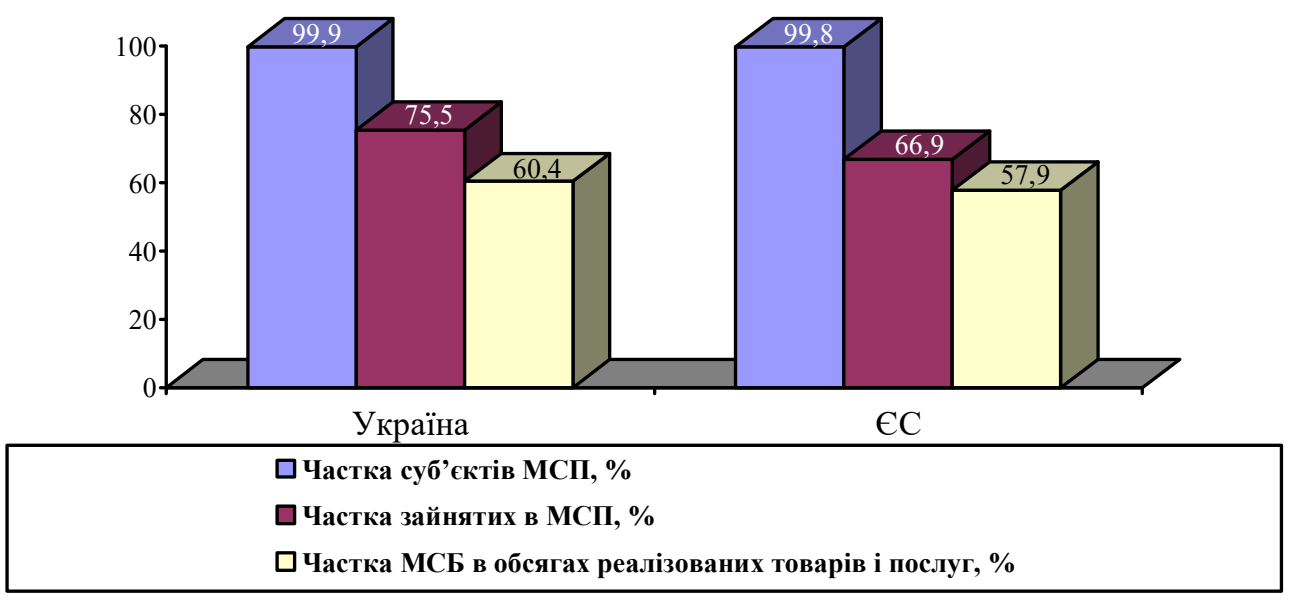

Рис. 3. Соціально-економічна значимість МСБ в Україні та ЄC (2017р.) [3; 5]

Попри це, все ж в експертному та науковому середовищі поширена думка, що підприємницький потенціал України розвинений недостатньо та має можливості для зростання. Відтак, виникає об'єктивна необхідність стимулювання розвитку МБ, що передбачає усунення основних перешкод для підприємницької та інвестиційної активності.

Як свідчать результати спільного дослідження ЛІГА:ЗАКОН та EBA в рамках проекту Unlimit Ukraine, серед основних факторів, що заважають веденню МБ в Україні, респонденти зазначають інфляцію, рівень податкового навантаження, корупцію, брак кваліфікованих фахівців (рис. 4). Показово, що тиск з боку контролюючих органів та незахищеність з боку судової влади як фактори-дестимулятори для розвитку МБ вказали відповідно лише $17 \%$ та $21 \%$.

Показовими є результати опитування респондентів щодо необхідних змін в житті країни на користь власного бізнесу (рис. 5).

Дослідження свідчать, що переважна більшість підприємців для успішного розвитку власного бізнесу, переглянули б податкове навантаження (22\%) та умови кредитування для забезпечення його доступності (15\%). 


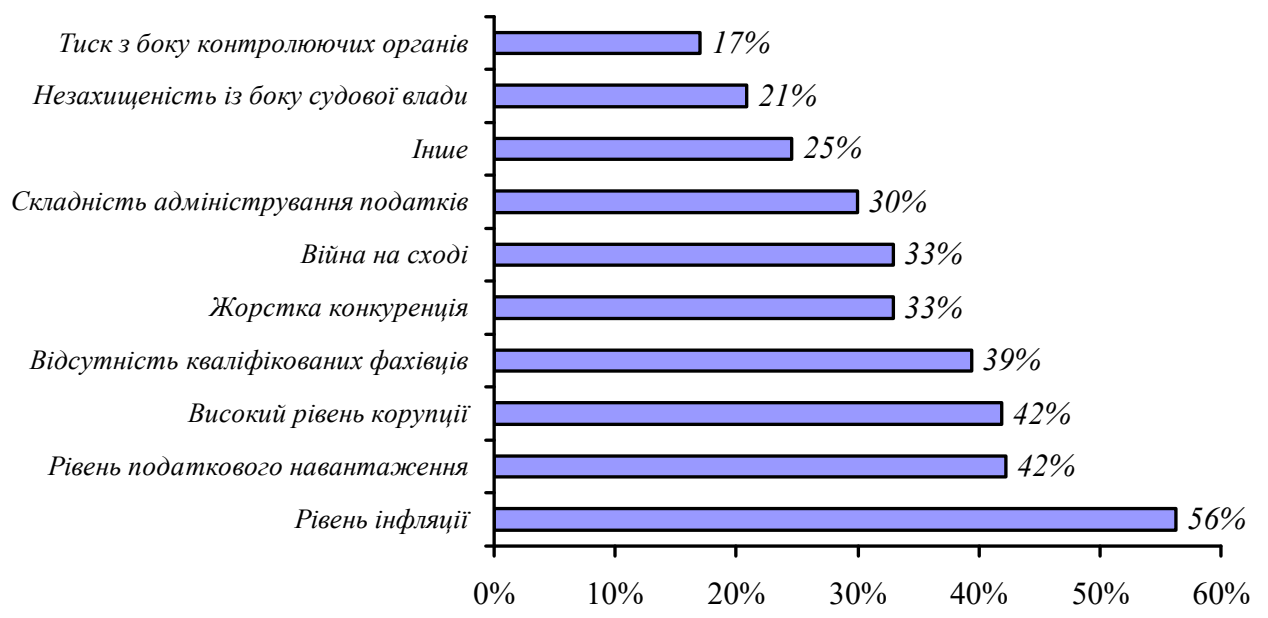

Рис. 4. Фактори, що заважають розвитку МБ в Україні (за результатами опитування респондентів), \% [4]

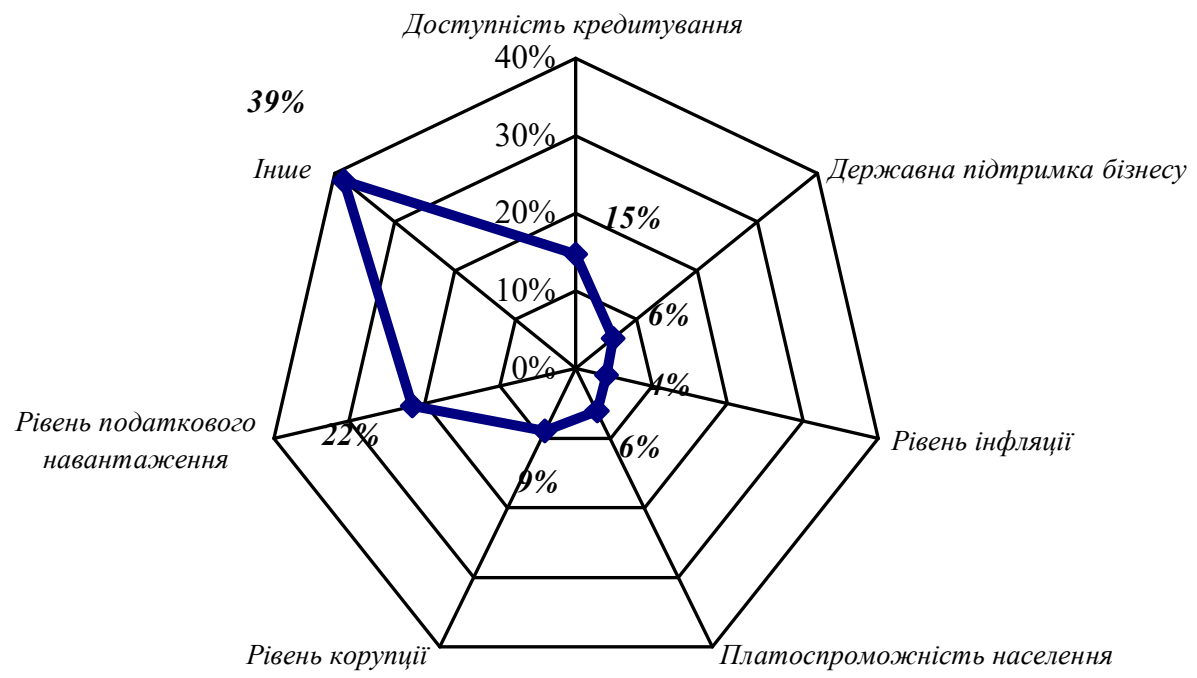

Рис. 5. Розподіл відповідей респондентів щодо необхідності зміни певної сфери в житті країни на користь власного бізнесу, \% [4]

Показовими в даному відношенні є рейтингові показники легкості ведення бізнесу. Як свідчать дані табл. 5 найбільш сприятливі умови для ведення бізнесу відзначаються в країнах з високим рівнем доходу, що є членами ОЕСР. 
Рейтинг країн-лідерів «Ведення бізнесу»-2016 та України

\begin{tabular}{|c|c|c|c|c|c|c|c|c|}
\hline & Сінгапур & $\begin{array}{c}\text { Нова Зела- } \\
\quad \text { ндія }\end{array}$ & Данія & $\begin{array}{c}\text { Республіка } \\
\text { Корея }\end{array}$ & 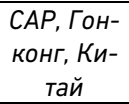 & $\begin{array}{l}\text { Велико- } \\
\text { британія }\end{array}$ & США & Україна \\
\hline $\begin{array}{c}\text { Рейтинг - легкість ве- } \\
\text { дення бізнесу }\end{array}$ & 1 & 2 & 3 & 4 & 5 & 6 & 7 & 83 \\
\hline \multicolumn{9}{|l|}{ За субіндексами: } \\
\hline $\begin{array}{c}\text { Реєстрація підпри- } \\
\text { ємств }\end{array}$ & 10 & 1 & 29 & 23 & 4 & 17 & 49 & 30 \\
\hline \begin{tabular}{|c|} 
Отримання дозволів \\
під будівництво \\
\end{tabular} & 1 & 3 & 5 & 28 & 7 & 23 & 33 & 140 \\
\hline \begin{tabular}{|c} 
Підключення до елект- \\
ропостачання \\
\end{tabular} & 6 & 31 & 12 & 1 & 9 & 15 & 44 & 137 \\
\hline Реєстрація власності & 17 & 1 & 9 & 40 & 59 & 45 & 34 & 61 \\
\hline Отримання кредиту & 19 & 1 & 28 & 42 & 19 & 19 & 2 & 19 \\
\hline Захист прав інвесторів & 1 & 1 & 20 & 8 & 1 & 4 & 35 & 88 \\
\hline Оподаткування & 5 & 22 & 12 & 29 & 4 & 15 & 53 & 107 \\
\hline Зовнішня торгівля & 41 & 55 & 1 & 31 & 47 & 38 & 34 & 109 \\
\hline $\begin{array}{c}\text { Виконання зобов' язань } \\
\text { за контрактом } \\
\end{array}$ & 1 & 15 & 37 & 2 & 22 & 33 & 21 & 98 \\
\hline $\begin{array}{c}\text { Дозвіл неплато- } \\
\text { спроможності }\end{array}$ & 27 & 31 & 9 & 4 & 26 & 13 & 5 & 141 \\
\hline
\end{tabular}

Україна, на жаль, належить до групи держав, ведення бізнесу в яких супроводжується значними перешкодами, поміж яких найбільш значимими є отримання різного роду дозволів, бар'єри при підключенні до електромереж та оподаткуванні, труднощі при захисті прав інвесторів. Це актуалізує необхідність дослідження світового досвіду стимулювання розвитку МБ. Загалом, в іноземних державах застосовується ціла низка інструментів стимулювання розвитку МБ (табл. 6).

Таблиця 6

Основні інструменти стимулювання МБ в іноземних державах

\begin{tabular}{|l|l|}
\hline \multicolumn{1}{|c|}{ Заходи державної підтримки МБ } & \multicolumn{1}{|c|}{ Країни } \\
\hline $\begin{array}{l}\text { Збільшення обсягів підтримки у вигляді га- } \\
\text { рантій по кредитах }\end{array}$ & $\begin{array}{l}\text { Канада, Чилі, Данія, Фінляндія, Угорщина, } \\
\text { Італія, Корея, Нідерланди, Словаччина, } \\
\text { Словенія, Іспанія, Швейцарія, Таїланд, } \\
\text { США, Великобританія }\end{array}$ \\
\hline $\begin{array}{l}\text { Надання особливих умов по гарантіях для } \\
\text { стартапів }\end{array}$ & Канада, Данія, Нідерланди \\
\hline $\begin{array}{l}\text { збільшення державних гарантій по експор- } \\
\text { тних операціях }\end{array}$ & $\begin{array}{l}\text { Канада, Данія, Фінляндія, Нідерланди, Но- } \\
\text { ва Зеландія, Швеція, Швейцарія, Іспанія, } \\
\text { Великобританія }\end{array}$ \\
\hline Збільшення долі прямого фінансування МБ & $\begin{array}{l}\text { Канада, Чилі, Угорщина, Корея, Сербія, } \\
\text { Словенія, Іспанія }\end{array}$ \\
\hline Субсидування процентних ставок & $\begin{array}{l}\text { Угорщина, Португалія, Росія, Іспанія, Туре- } \\
\text { ччина, Великобританія }\end{array}$ \\
\hline Податкові пільги, відстрочення платежів & $\begin{array}{l}\text { Франція, Ірландія, Італія, Нова Зеландія, } \\
\text { Іспанія, Великобританія, Росія }\end{array}$ \\
\hline $\begin{array}{l}\text { Створення банків, що спеціалізуються на } \\
\text { кредитуванні МБ, у тому числі кредитуючих } \\
\text { МБ з негативною процентною ставкою }\end{array}$ & Ірландія, Данія \\
\hline $\begin{array}{l}\text { Фондування Центральним банком кредит- } \\
\text { них організацій }\end{array}$ & Великобританія \\
\hline
\end{tabular}


Найбільш популярним інструментом державної підтримки МБ практично в усіх країнах $€$ надання державних гарантій по кредитах. Усі країни, вказані в таблиці вище (за винятком Ірландії і Нової Зеландіiі), мають свої державні гарантійні програми. В якості інших заходів підтримки сектора МБ у вказаних країнах використовуються як цільові кредити (наприклад, на розвиток інновацій) 3 пільговими умовами, мікрофінансування, гарантії по експортних операціях, податкові пільги.

Можна стверджувати, що на теперішній час законодавством України передбачено низку заходів, спрямованих на покращання ведення МБ в Україні та стимулювання підприємницької активності. Проте, реалізація цих заходів потребує більш досконалих та узгоджених заходів державного регулювання в рамках комплексного механізму стимулювання розвитку МБ.

Висновки і пропозиції. Незважаючи на виявлені позитивні зрушення щодо розвитку МБ в Україні, все ж підприємницький потенціал використовується недостатньо. Беручи до уваги досвід світових держав-лідерів, очевидно, що для покращення ситуації, український уряд повинен впровадити реформи, орієнтовані на бізнес: обмежити регуляції, переглянути податкові процедури, а також вжити заходів для боротьби з корупцією, політичною та макроекономічною нестабільністю.

Розділяємо думкою українських науковців, що для стимулювання МБ в Україні потрібно здійснити такі кроки: 1) провести регулятивну реформу, яка дасть змогу створити якісно нову ефективну, послідовну, прозору й зрозумілу систему державного регулювання, що захищатиме інтереси і підприємців, і споживачів; 2) усунути перепони на шляху розвитку підприємництва, значно скоротити витрати, пов'язані з функціонуванням МБ в офіційному секторі економіки; 3) створити державну кредитно-гарантійну установу з метою стимулювання комерційних банків до кредитування МБ з мінімальним фінансовим ризиком; 4) прискорити запровадження норм європейського страхового законодавства для страхування інвестиційних ризиків, що дасть змогу збільшити кількісні та якісні показники діяльності страхового ринку України; 5) проведення реальних реформ в напрямі деолігархізації та демонополізації економіки; 6) боротьба з корупцією.

Переконані, що відповідні зміни повинні проводитись із залученням представників МБ. Проведення зазначених реформ сприятиме формуванню нових умов ведення МБ, що дозволить залучити на- 
ціональні та іноземні інвестиції, забезпечити економічне зростання та підвищити добробут населення.

1. Варналій 3. С. Мале підприємництво: основи теорії і практики : монографія. 3-тє вид. К. : Товариство «Знання», КОО, 2005. 302 с. 2. Денега О. 3. Особливості функціонування і розвитку малих підприємств в умовах конкуренції : автореф. дис. ... канд. екон. наук : 08.06.01. Хмельницький, 2004. 25 с. 3. Діяльність суб'єктів великого, середнього, малого та мікропідприємництва : статистичний зібрник (2017). Державна служба статистики України. Київ, 2018. С. 343. 4. Індекс настроїв малого бізнесу. Спільне дослідження ЛІГА:ЗАКОН та EBA в рамках проекту Unlimit Ukraine. URL: https://eba.com.ua/wp-content/uploads/2018/03/Indeks-nastroyiv-malogobiznesu.pdf (дата звернення: 15.01.2019). 5. Статистична служба Європейського Союзу. URL: http://ec.europa.eu/eurostat (дата звернення: (20.01.2019). 6. Уманець Т. В., Ольвінська Ю. О., Лучакова О. В. Методи і моделі оцінювання розвитку малого бізнесу: мезо- і макрорівень : монографія. Донецьк : «ВІК», 2010. 250 с. 7. Хурса М. М. Мале підприємництво: економікоорганізаційні аспект діяльності : монографія. Полтава : РВВ ПУСКУ, 2009. $220 \mathrm{c}$.

\section{REFERENCES:}

1. Varnalii Z. S. Male pidpryiemnytstvo: osnovy teorii i praktyky : monohrafiia. 3-tie vyd. K. : Tovarystvo «Znannia», K00, 2005. 302 s. 2. Deneha 0. Z. Osoblyvosti funktsionuvannia i rozvytku malykh pidpryiemstv $v$ umovakh konkurentsii : avtoref. dys. ... kand. ekon. nauk : 08.06.01. Khmelnytskyi, 2004. 25 s. 3. Diialnist subiektiv velykoho, serednoho, maloho ta mikropidpryiemnytstva : statystychnyi zibrnyk (2017). Derzhavna sluzhba statystyky Ukrainy. Kyiv, 2018. S. 343. 4. Indeks nastroiv maloho biznesu. Spilne doslidzhennia LIHA:ZAKON ta EVA v ramkakh proektu Unlimit Ukraine. URL: $\quad$ https://eba.com.ua/wp-content/uploads/2018/03/Indeks-nastroyivmalogo-biznesu.pdf (data zvernennia: 15.01.2019). 5. Statystychna sluzhba Yev-ropeiskoho Soiuzu. URL: http://ec.europa.eu/eurostat (data zvernennia: (20.01.2019). 6. Umanets T. V., Olvinska Yu. O., Luchakova O. V. Metody i modeli otsiniuvannia rozvytku maloho biznesu: mezo- i makroriven : monohrafiia. Donetsk : «VIK», 2010. 250 s. 7. Khursa M. M. Male pidpryiemnytstvo: ekonomiko-orhanizatsiini aspekt diialnosti : monohrafiia. Poltava : RVV PUSKU, 2009. $220 \mathrm{~s}$.

Рецензент: д.е.н., професор Безтелесна Л. І. (НУВГП)

Yurchyk H. M., Candidate of Economics (Ph.D.), Associate Professor,

Koval A., Senior Student (National University of Water and

Environmental Engineering, Rivne) 
TRENDS OF DEVELOPMENT AND SOCIO-ECONOMIC SIGNIFICANCE OF SMALL BUSINESS IN UKRAINE

The purpose of this article is to study the tendencies and significance of small business in the context of increasing the efficiency of using its potential in ensuring social and economic development of the state. The decisive role in the development of small business in Ukraine belongs to the subjects of micro-entrepreneurship. Small business contributes to positive economic and social trends in the development of the state. Small businesses account for a significant proportion of manufactured and sold goods and services, employment and labor costs. In order to stimulate small business in Ukraine it is necessary: to carry out regulatory reform, which will enable to create a transparent system of state regulation; eliminate barriers to entrepreneurship development; to create a state credit and guarantee institution for small business lending; to introduce insurance of investment risks; carry out real reforms in the direction of deoligarchization and demonopolization of the economy; fight corruption.

Keywords: business, small business, entrepreneurship.

Юрчик Г. Н., к.э.н., доцент, Коваль А., студент (Национальный университет водного хозяйства и природопользования, г. Ровно)

\section{ТЕНДЕНЦИИ РАЗВИТИЯ И СОЦИАЛЬНО-ЭКОНОМИЧЕСКАЯ ЗНАЧИМОСТЬ МАЛОГО БИЗНЕСА В УКРАИНЕ}

Конкретизированы критерии идентификации малого бизнеса в Украине и иностранных государствах. Проанализированы основные тенденции развития малого бизнеса в национальной экономике. Определена значимость малого бизнеса в экономическом и социальном развитии государства. Предложено приоритетные направления стимулирования малого бизнеса в Украине.

Ключевые слова: бизнес, малый бизнес, предпринимательство. 